\title{
Prices of Foreign Library Materials: A Report
}

\author{
Frederick C. Lynden
}

In fall 1986 the author traveled to France, Germany, and the Netherlands on a grant from Martinus Nijhoff International to gather data on the prices of European library materials and encourage production of European academic book and serial price indexes. This study concludes that the best sources for data on the prices of academic library materials from Europe are vendors who supply American college and research libraries. At least two vendors are currently making available such data: Blackwell and Harrassowitz. In addition, there is a new draft international standard for price indexes; average price for pages or "signatures" is a promising method for capturing comparative price data on books and serials; and local cost studies are an effective means of calculating rising costs of foreign materials, especially with new technology available.

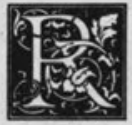

esearch libraries are very concerned about the buying power of their collection funds as the U.S. dollar has weakened over the past three years against foreign currencies. Budget planning for 1988-89 is about to begin in many universities and colleges, and collection managers must gather facts about the costs of library materials in order to project their needs. Research libraries, in particular, now purchase from 40 to 60 percent of their materials abroad, with particular emphasis on materials from France, Germany, and the Netherlands. Although these countries have a well-developed book trade, there is, unfortunately, very little published data available on the costs of academic materials from these countries.

There are two exceptions to the lack of data on academic material. The British have taken the leadership in determining the costs of academic materials with the British Academic Book Price Index, developed in $1974 .{ }^{1}$ This index covers only books of interest to Cambridge University
Library and hence to other academic libraries. In the United States, the Library Materials Price Index Committee, Resources Section, Resources and Technical Service Division, of the American Library Association has recently developed an American Academic Book Price Index. This index is vendor-based and covers only books supplied to academic libraries by three vendors. ${ }^{2}$ The U.S. also has a College Library Index based upon data from Choice. ${ }^{3}$ The above indexes are really subsets of general national data available in the U.S. from Publishers Weekly and in England from the Bookseller. It has long been recognized, however, that the academic subset differs from national data and that academic data are more reliable for projecting price changes for college and research libraries.

In summary, it would be a significant contribution to library budgetary planning if there were some standard and reliable sources of data on the costs of foreign materials. With research librarians spending millions of dollars on materials, it is

Frederick C. Lynden is Assistant University Librarian for Technical Services at Brown University, Providence, Rhode Island 02912. Lynden was a Martinus Nijhoff International West European Study Grant recipient. This article was revised February 1988. 
important for them to be able to do cost projections based upon real market figures. Computers now make it possible for publishers, vendors, and librarians to keep more accurate and complete data on price trends.

\section{PURPOSE AND METHODOLOGY}

The foreign price data study followed up on a proposal made at a LIBER (Ligue des Bibliothèques Européennes de Recherche) meeting in 1977 and also capitalized on an effort currently under way to develop international standard criteria for price indexes of library materials. In 1977, at a meeting of LIBER, Frederick C. Lynden, then chair of the Library Materials Price Index Committee, presented a paper regarding the "Library Materials Price Situation in the United States," in which he urged that libraries consider two steps: (1) developing international standards for price indexes and (2) creating academic subindexes to national price indexes in Europe and the U.S. ${ }^{4}$ The first recommended step has occurred. In fall 1986 the International Standards Organization Working Group 8, chaired by Morten Hein, Denmark, submitted to ISO a draft standard: "Price Indexes for Library Materials: Books and Serials." ${ }^{5}$ The second step will take time, but there is evidence that it would be possible to do this in France, Germany, and the Netherlands.

The chief purpose of the study was to gather information about which sources of price data are most reliable for academic libraries. The methodology was to visit vendors, book trade association officials, and librarians in France, Germany, and the Netherlands and to obtain information through interviews. The interviews sought to answer the following:

1. Existence of price data: which organizations collect price data on library materials, and how current are these data?

2. Publication: where are price studies/ indexes published, or how are they made available if they are not published?

3. Methodology: how are price studies/ indexes compiled, and what principles or standards do the compilers follow?

4. Use of price/studies/indexes: how are price studies/indexes used in research libraries, and how are the studies/indexes modified (if at all) to serve the purposes of libraries?

5. Improvements in data: are the orga. nizations that collect data aware of the standards developed in price reporting, particularly the American national standard and the ISO draft proposal?

In addition to gathering data on prices of library materials for France, Germany, and the Netherlands and publicizing this data, the study aimed to encourage production of price indexes where none are available and to make available information about the standards work that has been accomplished.

Before describing those data now available, it is worth explaining the uses that can be made of them. Information gathered from foreign price reports can be used by librarians:

1. to justify increases in the library's book budget

2. to allocate the materials budget by subject categories

3 . to analyze cost trends and plan future budgets

4. to aid librarians in interpreting collection program costs to funding authorities

5 . to determine the impact of material cost increases on other library programs

\section{ACADEMIC PRICE DATA CURRENTLY AVAILABLE}

As noted earlier, the British were the first to compile an Academic Book Price Index. In 1974 the Cambridge Library Management Research Unit (LMRU) began, under the direction of Len Schofield and Alan Cooper, "collecting data on the average prices of British Academic books by subject, based on the division of the copyright intake of the University Library Cambridge into academic and nonacademic items according to the library's criteria. ${ }^{16}$ The Tress Brown Index, previously used by British academic libraries, measured what university libraries were already buying, and the contention was that it therefore measured only the prices of books that these libraries could buy from limited budgets. LMRU felt it was more desirable to measure the prices of books that university libraries should buy.

The Cambridge library was one of four receiving books on copyright deposit, and 


\section{"The British Academic Book Price In- dex (BABPI) has been produced an- nually since 1974, and the results have been quite different than the Whitaker New Book Prices Index, a general price index."}

British National Bibliography (BNB) cards were sent to LMRU for all books selected for inclusion in the main catalog and therefore deemed to be of academic value. The average prices of these books were tallied, using forty-eight subject areas with totals for the ten major Dewey classifications. The British Academic Book Price Index (BABPI) has been produced annually since 1974, and the results have been quite different than the Whitaker New Book Prices Index, a general price index. In 1983, however, BABPI compiler Lawraine Wood noticed that from 1982 to 1983 the average price had decreased, whereas the general retail book price index had shown an increase. Upon examining the causes, Wood discovered that a large number of pre-1982 books had been included in the index because the BNB was catching up on its cataloging. Upon further examination, Wood discovered an increasing number of unpriced items that, by practice, had been excluded from the index. A sample revealed that the unpriced items had caused a price understatement of as much as 25 percent in the index. Therefore LMRU, which had by then become the Centre for Library and Information Management (CLAIM) at Loughborough University, realized that the source of price data was not reliable. $^{7}$

At about this time, Wood was invited to attend meetings of the Library Materials Price Index Committee, which was grappling with the problems of creating an academic book price index for the U.S. Without any source, such as a depository system, to use for such an index, the committee decided to use data from vendors supplying approval- and blanket-plan books to American academic libraries. By happy coincidence $B$. H. Blackwell representatives in attendance told Wood that they could provide data for a British index, and she returned to England with the recommendation that the data used there also be vendor supplied. Currently the index is created from data supplied by Blackwell. All of this is reported because it illustrates several principles that underlie the foreign price data study:

1. Academic libraries should use academic price indexes because they differ from the general price indexes.

2. Vendor data can be a reliable source of information because they are up-todate and are frequently supplied from computerized records.

3. When there is no depository system, vendor selections of current titles for academic libraries can be an excellent source of information.

4. Vendors classify the books that they supply by subject in order to tailor their selections to libraries' interests.

This movement to create an academic subset of price indexes took place only in the U.S. and England. Thus, it seemed logical to extend these principles to materials from France, Germany, and the Netherlands. It is also important to be aware of the general indexes from these countries because these can show inconsistencies in academic price data that might be due to anomalies in the source data.

In the U.S. the Bowker Annual of Library and Book Trade Information makes available general and some academic price information for foreign publications. In 1986, the Bowker Annual published information about British book prices from CLAIM, using the data from Blackwell; on German book prices from Buch and Buchhandel in Zahlen, produced by the Boersenverein des Deutschen Buchhandels (a national trade organization of booksellers); and Latin American book costs, gathered from several research libraries, among them the Library of Congress. ${ }^{9}$ There is obviously very little information in the Bowker Annual on academic foreign prices, and no information on prices in the Netherlands or France. Recently, the Book Research Quarterly published an article by Sally F. Williams that contains a table showing the sources for published price reports. ${ }^{10}$ There is no information again on the prices of "academic" materials in France 
and the Netherlands.

In summary, progress on academic book price indexes has been made chiefly in the U.S. and Britain. These indexes now rely heavily upon vendor data that are machine-readable and are preselected for the academic market. National price data are useful in discovering trends, but are not as applicable to academic libraries.

\section{LIBER AND PRICE INDEX STANDARD PROPOSALS}

Another factor that caused this study to be started was the general interest, expressed at the LIBER meeting in 1977, in the production of academic price indexes for library materials from European countries. A working party consisting of J. L. Schofield, England; A. W. WamstekerMeijer, the Netherlands; and E. Mittler, West Germany, proposed work on price indexes for other European countries. Their proposal was for Western European countries to produce indexes for their own countries on the prices of academic library materials. At the LIBER meeting in April 1977, it was proposed to have "indexes from the four countries which together produce the main part of the European output: United Kingdom, France, Germany, and the Netherlands. ${ }^{18}$ It was further recommended that LIBER contact appropriate parties in each country, and that LIBER publish the indexes as separate publications. One or two standard criteria also emerged: the UNESCO classification was felt to be desirable for subject divisions and the total number of publications per category was to be listed. After over ten years of inaction, LIBER will put the subject of price indexes on its agenda for its April 1989 general meeting in Spain.

Although there was no progress on the academic price indexes, there was progress on a standard that could be used internationally. Working Group 8 of the International Organization for Standardization, Technical Committee 46 was established in 1983 to consider the creation of an international standard for price indexes for library materials. Headed by Morten Hein, Denmark, the group included representatives from England, U.S., Sweden, France, and Germany. After five meetings, the Working Group submitted a draft proposal (9230) in November 1985 that was accepted after some technical objections were resolved and has now gone out as an international draft standard. The draft standard has the following distinctive features:

1. Covers price indexes for books and serials; nonbook media are not included.

2. Distinguishes between national indexes measuring prices and local indexes measuring costs.

3. Allows for separate indexes for paperbacks and hardcover publications but indicates a preference for including the two formats together.

4. Uses the UNESCO breakdown for subjects with its twenty-five subject groups.

5. Permits the compilation of serial price indexes by either national agencies or subscription agents (book prices for national indexes may be taken from national bibliographic or trade sources or may be calculated by direct observation).

\section{"The international draft standard 'Price Indexes for Library Materials: Books and Serials,' which records common criteria for creators of price indexes, can be used by those pro- ducing price reports for academic li- braries."}

The international draft standard "Price Indexes for Library Materials: Books and Serials," which records common criteria for creators of price indexes, can be used by those producing price reports for academic libraries. One dividend of the foreign price data study was that vendors, librarians, and national publishing organizations were made aware of the efforts toward creating the standard, about which surprisingly few were aware. In summary, LIBER proposed in 1977 to create academic book price indexes for Western European countries. Although no product emerged, the proposal is under active consideration again. However, there was progress made in developing an 
international standard that is now in a draft standard stage. This proposal should be useful to compilers of price data from European countries because it will allow for comparability among various countries' data.

\section{THE FOREIGN PRICE DATA STUDY}

Hence, the foreign price data study concentrated on discovering what was available. The primary methodology was interviews with librarians, publishers, and booksellers. Following is what was learned about price data available from vendors, bookselling associations, and librarians in each country.

\section{Price data from the Netherlands}

American academic librarians are principally interested in English-language materials from the Netherlands. Dutch collections in American academic libraries are not extensive, but English-language Dutch publications from such publishers as Elsevier, De Gruyter, North Holland, Brill, and Nijhoff, among others, are purchased heavily by American libraries. The Bookseller's Association, Stichting Speurwerk, Betreffende het Boek in Amsterdam (Frederiksplein 1, 1017 XK Amsterdam-C) keeps statistics on Dutch book prices and publishes them regularly. A synopsis is published in Boekblad, a weekly trade magazine similar to $P u b$ lishers Weekly. Data have come from the Royal Library since 1983. Table 1 gives summary data since $1983 .{ }^{11}$ All prices are in Dutch guilders. More detailed tables show production and costs by subject. The tables use UNESCO subject headings.

Of more direct interest to American academic librarians are the changes in the costs of English language and other fo:eign language publications. Unfortunately, there is no direct source of information on the English language and other foreign language publications and their average costs. There are a couple of possibilities for obtaining information on Dutch, English and other foreignlanguage titles: Stichting Speurwerk's Boeken Titelproduktie Vreemdtalig (Book Title Production for Foreign Languages) or the monthly publication of Nijhoff Information. Both of these publications list not only English-language titles but also titles in German, French, and other languages produced in the Netherlands. The advantage to the latter is that it contains only those titles of special interest to academic libraries, whereas the Stichting Speurwerk's figures include statistics of all publications in these languages. One assumption would be that academic and scientific title production in foreign language constitutes the primary proportion of Dutch foreign-language publishing. Nevertheless, there is no price information tied directly to these figures. In 1985, for example, with sports books and children's books excluded, there were 1,270 Dutch books published in English, German, French, and other foreign languages. Stichting Speurwerk includes only a count of the titles. Since Nijhoff Information contains price information, it seems like a better source for academic libraries. In fact, it might serve as the database of the academic subset for Dutch books purchased by American libraries.

In addition to the general information provided by associations supported by the book trade, vendors can supply information of specific interest to academic libraries. The publication Nijhoff Information is one example. Many vendors now have

TABLE 1

AVERAGE PRICES DUTCH BOOKS

(Boeken-Titelproduktie)

\begin{tabular}{llcrr}
\hline \hline Year & New Titles & New Editions & All Titles & \% Incr. \\
\hline 1986 & $46.50 \mathrm{fl}$. & $26.30 \mathrm{fl}$. & $40.30 \mathrm{fl}$. & 8.0 \\
1985 & $41.70 \mathrm{fl}$. & $25.60 \mathrm{fl}$. & $37.30 \mathrm{fl}$. & 3.8 \\
1984 & $40.50 \mathrm{fl}$ & $24.80 \mathrm{fl}$. & $35.90 \mathrm{fl}$. & 10.8 \\
1983 & $37.40 \mathrm{fl}$. & $21.80 \mathrm{fl}$. & $32.40 \mathrm{fl}$. & \\
\hline
\end{tabular}


considerable information available as a byproduct of their computerized files. In the U.S., Baker and Taylor, Blackwell North America, and Coutts currently provide customers with data on book prices; data from their programs make up the price index of American academic books. Martinus Nijhoff is in the process of computerizing all of its records and, as a part of this computerization, it will have the capability of building in price data on materials both monographic and serial, supplied to academic libraries. The computer system will be ready in 1988, and currently $\mathrm{Ni}-$ jhoff is querying customers about their needs from the computerized system.

In discussions with the monographs and serials managers at Nijhoff, it was learned that the managers felt that actual local inflation was not substantial, but that American librarians should be more aware of the currency changes that are really hurting the ability of academic librarians to purchase. They pointed out that the currency change made Dutch materials more expensive. Regarding future price information both agreed that, in the new system, Nijhoff will have the capability of delivering price reports and would be willing to publish general information of value to the library community. One of the two was aware of the standard on price indexes that ISO has in draft form. The monographic manager said that Nijhoff Information was available on slip form and could be used for compiling price data. (One other Dutch vendor, Swets \& Zeitlinger, has produced price reports on books and journals supplied to academic libraries.)

\section{Price Data from France}

National data in France are available from Cercle de la Librairie and appear annually in Livres Hebdo in summary form.
All of these reports are generated by a computer system called Electre that is managed by the Cercle de la Librairie and available to anyone in France through Minitel, the government owned and managed system that makes free terminals available to anyone in the country. Minitel now has 2 million units available in France. The data on book prices comes from Les Livres Disponibles, which is similar to Books in Print. Table 2 shows the general price trends for books in France. ${ }^{12}$

As can be seen, there have been no double digit increases in the costs of French books in recent years. By a decree of 1954, the Syndicat National de l'Edition keeps statistics on books for the Institut National de la Statistique et des Etudes Economie (INSEE). The Syndicat National de l'Edition is part of the Cercle de la Librairie. The Cercle is a principal source for statistics and information on the book trade in France (Cercle de Librairie, 35, rue Gregoire de-Tours, 75279 Paris, Cedex 06).

Two major vendors for American academic libraries, Jean Touzot and Aux Amateurs des Livres, were visited in Paris. Jean Touzot's invoicing is computerized and provides total books sold and average cost without any subject separation. He has not been asked for information, and he sees computerization as less important than other facets of the business. He sees the intellectual (i.e., selection) side of the business as more important. Touzot also supplies journals, but has the same difficulties in supplying price information. Aux Amateurs des Livres is totally computerized, books and journals, but does not have the programs to provide price information. Nevertheless, it is possible to do so, according to owner Alain Baudry. It was noted that there had been little demand for price information although he does receive inquiries at ALA. He indi-

TABLE 2

INDEX PRICES FOR FRENCH BOOKS

\begin{tabular}{lccc}
\hline \hline Year & $\begin{array}{c}\text { Index for } \\
\text { Nonscholarly Books }\end{array}$ & General Index & \% Incr. \\
\hline 1986 & 179.1 & 162.2 & 2.66 \\
1985 & 170.7 & 158.0 & 5.8 \\
1984 & 162.0 & 149.3 & \\
\hline
\end{tabular}

Source: INSEE. 
cated that the tendency for price increases has been less dramatic in the last few years, primarily because costs are stable and are under control thanks to technology. Aux Amateurs des Livres also supplies journals and series and could provide price data using a computer. Prices by subject could be provided by UDC class.

Baudry also mentioned that data are being gathered on university press publications. A catalog, Catalogue Automatise des Publications d'Origine Universitaire (CADOU), which will be run by DBMIST (Direction des Bibliotheques, des Musees et de l'Information Scientifique et Technique), is intended to provide a machinereadable database of information on books and serials originating from universities that will include price; since it is voluntary, however, it will probably not be comprehensive. At the moment, it is not possible to obtain academic book and serial price information from either vendors or other sources, but there are some promising possibilities for the future. At least one major vendor is computerized, and the French government is requesting that publishers provide machine-readable data on publications of university origin.

\section{Price Data on German Publications}

National data on German book prices are available from Buch und Buchhandel in Zahlen published by the Boersenverein des Deutschen Buchhandels. As noted earlier, the summary tables from this annual publication have been published in Bowker Annual since 1974. They show the average prices by subject using the UNESCO subject headings. (Incidentally, the bookselling community would prefer not to use UNESCO headings, but the compiler, Horst Machill, finds these subject headings of value for comparisons. Since the ISO standard uses these headings, Machill was pleased to get reinforcement for his views.) Table 3 shows general German book prices. ${ }^{13}$ Periodical price information can be obtained from the Verband der Zeitschriften, located in Bad Godesberg. The source of Buch und Buchhandel in Zahlen is Deutsche Bibliographie $(D B)$, although as many as 25 percent of its titles are unpriced. $D B$ also uses sixty-three categories that Machill compresses into the twenty-five used by UNESCO. One feature of Buch und Buchhandel in Zahlen that might well be copied is its Bogen Preisen or the average price per sixteen pages. Instead of comparing volumes it might be more accurate to compare page prices. For journal prices, Charles Hamaker urges index makers to consider not only page prices but distribution of prices among journals. ${ }^{14}$

Although Buch und Buchhandel in Zahlen (BUBIZ) is an important measure of the costs of German books, academic librarians have been uncertain whether it really records the costs for academic books. In addition, due to a major change in coverage, the $B U B I Z$ index temporarily will be of no use to librarians, even as a general index. In 1986 DB increased its coverage of titles: the figures showed an increase over 1985 of almost 9 percent in the representation of titles costing under 10 marks and a decrease of 8 percent in titles costing more than DM25. As a result, the overall average dropped from DM32.57 in 1985 to DM25.47 in 1986. The coverage of titles will continue at the same level so that in a few years BUBIZ will again be of value as a general index of prices. Recently an article by Steven E. Thompson pointed out that

TABLE 3

GERMAN BOOK PRICES

(Buch und Buchhandel in Zahlen)

\begin{tabular}{lrr}
\hline \hline Year* & Avg. Cost per Title & \% Incr. \\
\hline 1985 & $32.57 \mathrm{DM}$ & 8.4 \\
1984 & $30.06 \mathrm{DM}$ & 7.6 \\
1983 & $27.93 \mathrm{DM}$ & 5.5 \\
1982 & $26.48 \mathrm{DM}$ & 5.5 \\
\hline
\end{tabular}

*1986 not included due to a radical change in reporting. 
there are significant differences between an academic and general index. ${ }^{15}$ The example used was a comparison of Buch und Buchhandel in Zahlen and an index from the Otto Harrassowitz firm, a vendor who supplies exclusively to academic libraries.

The major vendor for U.S. academic libraries in Germany, Otto Harrassowitz, has compiled average price data since 1982 for books supplied on the firm's blanketorder plan (see table 4). The mix of titles offered to academic libraries obviously affects the overall average price as well as the percentage increase. As can be seen, the local inflation has not been very high for German academic books. The data from Otto Harrassowitz can be very useful to academic libraries. Combined with information on the changes in the value of currency, such data can inform budgetary authorities on the trends of prices for materials from Germany. With permission from Harrassowitz, the Library Materials Price Index Committee has decided to publish the Harrassowitz figures in the Bowker Annual starting in 1988 since these figures are of more relevance to the academic book market and more up-to-date. In view of the problems with the general index of German book prices, the Harrassowitz study is an especially invaluable source to academic libraries.

Overall, the Harrassowitz price study is of great value. It has the following features of interest to academic libraries. First, the classification system used is LC. Second, the index covers publications from German-speaking countries, not just Germany. Therefore, it includes Austria, Switzerland, and DDR. There are plans to have a country breakdown. Third, it includes both paperbound and hardcover books together. If the countries of publication are indicated for each title and the classification system is changed to UNESCO, the price study meets all the criteria for indexes from the ISO draft proposal. The portion of total German-language materials that were considered of academic level was estimated to be 18.75 percent.

In summary, the above experience indicates there need to be several conditions present in order to produce academic indexes for the countries of France, Germany, and the Netherlands:

1. There need to be vendors who supply principally academic libraries and have their files computerized.

2. The vendors need to be able to breakdown the data by:

a) Total volumes shipped, or titles in the case of periodicals.

b) Total cost in the country of origin's currency.

c) Total average prices.

d) Subject classification, preferably UNESCO, but LC is acceptable.

e) Imprint year.

f) Country of publication.

3 . The vendors must also be able to distinguish formats, such as book, periodical, microform, etc.

4. The vendor should be aware of the standards that might be applicable, such as the ISO draft proposal or the National Information Standards Organization (NISO) standard.

5. The vendors must be willing to have the data published and shared with librarians, and they should be willing to share it on computer tape.

When these conditions are met, it will be possible to produce academic book and journal price studies and indexes. As noted above, the Blackwell firm has come to the rescue of the British Academic Book Price Index, and several firms are willingly

TABLE 4

GERMAN ACADEMIC BOOKS

(Otto Harrassowitz)

\begin{tabular}{lcccr}
\hline \hline Year & Titles & Amount (DM) & Avg. Pr. (DM) & \% Incr. \\
\hline 1987 & 19,122 & $1,201,751.10$ & 62.84 & $6.5 \%$ \\
1986 & 21,745 & $1,282,577.20$ & 58.98 & $-1.1 \%$ \\
1985 & 19,059 & $1,136,512.22$ & 59.63 & $-1.0 \%$ \\
1984 & 16,504 & $944,228.15$ & 60.24 & \\
\hline
\end{tabular}


participating in the American academic book price index project. It appears that the Harrassowitz price study meets most, if not all, of the criteria from above and that there are vendors in the other two countries who can meet these criteria.

Next, the paper will discuss budgeting practices in some libraries in France, the Netherlands, and Germany, and then it will examine discriminatory pricing and suggest steps that might be taken to ease its effects. Finally, the paper will report on conclusions that can be drawn from the study and make some recommendations for the future.

\section{Library Budgeting in the Netherlands}

Although it was only possible to visit the University of Groningen's library, the director was able to speak about activities in the other fifteen university libraries in the Netherlands. There is an association of University and National Libraries, similar to SCONUL in England and ARL in the United States. According to Willem Koops, director at Groningen, this group is collecting information on the costs of materials to Dutch libraries. Since the organization is voluntary and not everyone has cooperated, there is no book price index for academic libraries. Many libraries such as Groningen, however, have their local acquisitions computerized and can provide quite accurate data on books, continuations, and subscriptions. As noted later, in the Netherlands, library serial costs are rising at a very fast rate. One way the libraries in the Netherlands have dealt with higher costs is to cooperate nationally on acquisitions. To avoid gaps in collections, there is an agreement that a library cannot cancel a subscription when there is no other subscription for that title in the country. There have been some political problems in this area as well.

Many universities in the Netherlands have very decentralized library systems where department and institute libraries tend to be autonomous and not always cooperative. The budget at Groningen is for the central library, and the institute libraries pay the central library for services. At Groningen automation costs have risen since the library is a member of Pica, the national network, and also has its own system for acquisitions, cataloging, and serials. As noted earlier, the costs of serials, many of which must come from overseas, are rising faster than monographic costs, and a study done locally at Groningen was used to justify more funds for books. For example, at Groningen an expenditure pattern has emerged (see table 5). As can be seen, serials costs are outstripping monographic costs, and the library administration is interested in better data on materials costs in order to be able to project costs. The general harm done by declining budgets was expressed in a questionnaire sent out by the International Publishing Association in June 1986. The cover letter on the questionnaire notes: "IPA wishes to draw the attention of national and regional authorities on the damaging trend of declining library budgets for education, research and public information." 16 The questionnaire goes on to ask for library data from IPA members on library buying during the last three years.

\section{Library Budgeting in France}

Although it was only possible to visit one French library, the Sorbonne in Paris, its conservateur Michel Marion gave me much information about the budgeting process there that he said was similar elsewhere in France. According to Marion, the materials budget has not been keeping up with the costs of materials, particularly the costs of foreign materials. French importers of foreign materials impose a

TABLE 5

EXPENDITURE PATTERN

\begin{tabular}{lccr}
\hline \hline & 1980 & 1982 & \multicolumn{1}{c}{1985} \\
\hline Books & $1,302,630 \mathrm{fl}$. & $1,015,213 \mathrm{fl}$. & $863,610 \mathrm{fl}$. \\
Continuations & $307,933 \mathrm{fl}$. & $402,778 \mathrm{fl}$. & $485,786 \mathrm{fl}$. \\
Journals & $1,292,739 \mathrm{fl}$. & $1,817,868 \mathrm{fl}$. & $2,109,756 \mathrm{fl}$. \\
\hline
\end{tabular}


value-added tax (VAT), which makes library materials very expensive. The funds for books come directly from the national government ( 80 percent) and from the university ( 20 percent) through tuition. There are no private funds available for libraries, but sometimes the library does get special funds for buying materials through departments. Journals have priority over books, but overall the funds are totally insufficient to stock the library. The library seems to be relying more on exchange now as well. Theses are used for exchange purposes. Unfortunately, at the Sorbonne there are no computers available for managing materials funds. The budget justification at the Sorbonne depends upon data showing the cost rise, and departmental advocacy for needs on building and maintaining collections.

\section{"... the cost of periodicals to which [French] libraries subscribe has in- creased between 1981 and 1986 by an average of 7 points more than the cost of living."}

According to Marion, Pierre Carbone from DBMIST is aware of price trends for materials and what is being done at French university libraries. A report sent to the author by Carbone indicated that the cost of "periodicals to which [French] libraries subscribe has increased between 1981 and 1986 by an average of 7 points more than the cost of living." Books showed less of an increase during this period because "libraries have chosen to maintain their periodical subscriptions to the detriment of their book purchases; consequently, they have in most cases purchased cheaper monographs ..."' DBMIST also has computers available for keeping proper records.

\section{Library Budgeting in Germany}

Two libraries in Germany were visited and there was correspondence with another library. In Berlin, the Technische Universitaetsbibliothek Director Helmut
Sontag and his staff indicated that serials are consuming 50 to 60 percent of his budget, and there is very little room for the purchasing of monographs. The budgetary process is automated at the Technische Universitaetsbibliothek and the other two libraries mentioned here. The Preussicher Staatsbibliothek and the Heidelberg Universitaetsbibliothek are also completely automated for acquisitions. At the Staatsbibliothek Preussicher Kulturbesitz (SBPK), Kurt Wolfgang Drozd, head of acquisitions, has created an automated price index for books and periodicals showing price development since 1980 by subject area and by country. Many academic libraries use this index for comparison but compile their own price studies to show the trends.

University libraries in Europe, which are state-funded institutions, have not typically obtained private donations for acquisitions, since seeking private funding is not the practice, and philanthropy does not occur. In Germany many universities have a second source of funding from the government, i.e., research monies from a government research council. At the Universitaetsbibliothek Heidelberg, the library, in addition to regular funds, gets supplementary monies from the Deutsche Forschungsgemeinschaft (German Research Council) for the support of foreign materials in special subject areas designated according to a national collection plan. Marion MallmannBiehler, deputy librarian, supplied the Heidelberg budget for acquisitions, which is computer produced. It is divided by books, series, continuations, magazines, newspapers, antiquarian monographs, antiquarian magazines, and manuscripts. Each segment also shows the foreign costs. The library also has a detailed subject breakdown.

One of the factors that has reduced funds available to research libraries in Germany is the phenomenal growth of university libraries over the past twenty years. Since the national and state governments support the budgets, a larger number of libraries reduces expenditures overall. There has been considerable research in Germany on the costs of materials. Of 
particular interest is the work by Rolf Griebel, Bamberg University, whose recent address to the national library association on "Preisindizes und Haushaltungsplanung" is a very complete explication of what is happening in the price index field. ${ }^{17}$ Griebel is seeking to develop an academic index as well and looking toward vendors as the most productive source for price data.

In summary, there are some encouraging signs for collection managers who need more data from Europe. First, research libraries in the Netherlands, Germany, and France are moving toward better informed decisions through the use of computerized data. Second, serials expenditures appear to be outstripping monographic expenditures in European libraries as well (although this may change somewhat with the strengthening of European currencies). Third, libraries are increasingly concerned about the minimal funding available and are relying more on resource-sharing arrangements. One promising effort is occurring in Germany where a national resource-sharing plan is supported by government funds. This could provide a model for the United States. ${ }^{18}$ Fourth, private funding for acquisitions is not available to European institutions that are predominately state supported institutions. Finally, there is interest in obtaining price data and there are efforts underway to collect better data.

\section{Effects of the Dollar's Loss in Value}

The most deleterious effects on acquisition budgets have resulted from the continued downward trend of the dollar against West European currencies. Library Issues (Ann Arbor, Mountainside Publishing) has been reporting on the changes in the dollar's value in a section of the newsletter entitled "Dollar Watch." In March 1987 , it reported on the dollar's loss in value during 1986: Britain ( -2.0 percent), France ( -14.2 percent), Germany $(-20.3$ percent), Japan (-20.7 percent), Netherlands (-20.1 percent), and Spain $(-13.5$ percent). The dollar's average loss in 1986 was 13.1 percent. ${ }^{19}$ The vendors visited in France, Germany, and the Netherlands saw the weakening dollar as a serious threat to American acquisition programs. The dollar downturn can be added right on the top of inflationary increases when calculating total increases. However, it is best to keep figures separate for presenting a case to budgetary authorities since many institutions are willing to give libraries special increases to counteract currency changes.

At Brown University Library, the combination of inflation in the prices of books and journals and the dollar's losses resulted in a 1988-89 budgetary request for a 16.2 percent overall hike in funds. Brown's purchases from selected vendors in Great Britain, France, Italy, the Netherlands, Spain, and West Germany in $1986-87$ totaled $\$ 498,478$. Approximately 40 percent of all materials purchases were foreign. Using Brown's total foreign expenditures of $\$ 927,559$ and applying foreign currency changes from July 1986 to June 1987, it is estimated that Brown lost $\$ 152,956$ or had a 14.2 percent increase in costs for foreign materials due to the dollar's loss in value. It can be seen from previous data on publication price increases that the currency changes have more effect than the inflationary increases. Vendors said that American librarians need to keep a better record of foreign currency changes than they have.

One practice discussed at every visit was that of discriminatory pricing, a practice by British journal publishers, and a German publisher of chemistry serials, to charge North American libraries a higher price than the price charged in the country of origin. Although this practice originated in the early 1980 s when publishers were trying to recoup the losses when the dollar was strong against foreign currencies, it only came under the scrutiny of librarians in $1984 .{ }^{20}$ However, since the dollar has weakened there has not been a compensatory decrease in the prices of these journals. Every vendor was aware of this practice, condemned it, but had no recommendation for resolving the situation. They also uniformly indicated that in their countries American publication prices were hiked upwards. For example, in the Netherlands booksellers are obliged to use special exchange rates set by the 
Dutch Bookselling Association in consultation with the Ministry of Economic Affairs. In France the price for import books is free-floating, i.e., the vendor can use a fixed price or not depending on his own preference. As Knut Dorn of Otto Harrassowitz put it: "The Harrassowitz position is clear. A publisher cannot single out one group of libraries. It is unfair." There were some suggestions about how to lessen the effects of price discrimination, currency fluctuation, and inflation. These recommendations follow, along with the conclusions of this study and recommendations for the future.

\section{Proposals to Counteract Higher Prices}

Many of the vendors advocated prepayment and planned to prepay for serials. There are three advantages: in the currency of the vendor, the value is frozen at the point of purchase; multiple invoice processing and payment (actual processing of checks) can be eliminated; and interest can be collected from the vendors. The first advantage may be a risk, since if the dollar gains in value, freezing the payment at a lower rate will mean a loss for the library. The advantages of reducing invoice and check processing are clear, and the interest rates can be calculated to determine if better interest might be gained locally. Some interest rates can be very attractive. In 1987, for example, one vendor offered as high as 6.9 percent if the prepayment invoice for 1988 was paid by January 15, 1987.

Another approach vendors offered was deposit accounts for books. Deposit accounts have the same advantages as serial prepayments. They can freeze currency value; reduce processing; and offer interest advantages. A third method suggested by vendors was to purchase foreign currency and use it to buy books and serials. Brown is considering this approach. Should the dollar strengthen, then the university would hold on to marks, guilders, or pounds and wait until the dollar weakened again. The principal disadvantage to this approach is that it requires large purchases and there are costs for changing funds. Some institutions use this approach, but generally a university would purchase currency not just for the library but for other segments of the campus requiring foreign funds.

"Prepayment, deposit, or foreign
currency trading can help reduce
costs, but other methods for counter-
acting higher prices may also be em-
ployed."

Prepayment, deposit, or foreign currency trading can help reduce costs, but other methods for counteracting higher foreign prices may also be employed. For example, a stronger budget proposal that accounts for the changes in the dollar's strength can make an impression on budgetary authorities. Therefore, it is necessary to be aware not only of inflationary increases but also of the value of the dollar. In many institutions, when it is shown how the pressures of foreign currency losses are affecting materials purchases, many institutions are willing to compensate for these losses to maintain buying power. A complete discussion of various approaches to managing rising materials costs is contained in a paper delivered by Frederick C. Lynden at the February 1987 conference in Oklahoma on "Acquisitions, Budgets and Materials Cost: Issues and Approaches. ${ }^{\prime 21}$ Other approaches are recommended in "Periodical Prices: a History and Discussion" by Ann Okerson. ${ }^{22}$

Finally, it should be noted that if unreasonable and excessive pricing of foreign journals should continue, it will be necessary to consider external political pressures such as meeting with publishers, public exposure of pricing practices, and/ or cancellation of journals from offending publishers. The continued excessive pricing practices will ultimately be damaging to scholarly communication.

\section{GATHERING FOREIGN PRICE DATA IN THE FUTURE}

Visits to vendors, bookselling and trade associations, and librarians have indicated the advantages of gathering data from for- 
eign vendors who supply to American academic libraries. Libraries need to encourage vendors to supply such data, both institutional and national. There also needs to be more regular communication among price experts in each country. This study provides one example of the benefits of such communication. Rolf Griebel, an expert on German book prices, was to be visited as part of this study. He was put in touch with Knut Dorn of Harrassowitz. Although he was unable to participate in the study due to a death in the family, his contacts with Dorn suggested to him the possibility of using vendor data for constructing a German academic book and serial price index. This type of crossfertilization has not occurred regularly because there have been too few meetings of experts on library materials prices from Europe and the United States. Morten Hein, chair of ISO Working Group 8, wrote in August 1986 that he thought it would be of value to set up an international mailing list on price indexes. There have also been contacts with Peter Mann of the Centre for Library and Information Management (now called Library and Information Statistics Unit), which produces the British Academic Book Price Index; he has recommended a meeting among international experts. LIBER plans a meeting in April 1989 to consider, among other things, the price index question. Such a meeting would be another significant step toward better data. There are still questions remaining. For example, who are the experts on French academic prices? Can LIBER assemble the experts interested in pursuing the production of price indexes? Which vendors are interested in participating in such a meeting? It is important that such meetings will occur soon in order to capture the momentum generated by interest of both librarians and vendors. These meetings will hopefully identify what problems still exist that might prevent the production of academic book and serial price indexes; which countries should have indexes; what standards these indexes should follow; who should be responsible for producing them; and how they could best be distributed to the library community.

\section{CONCLUSION}

The following general conclusions emerged from the study:

- Although there are general data from publishing/bookselling associations available in France, Germany, and the Netherlands, vendors are really the best source of information on foreign price trends for "academic" titles.

- Actual inflation rates for foreign titles are not as high as exchange rates. It is the declining value of the dollar that is imperiling budgets. Librarians should therefore spend time tracking currency changes that are heavily affecting the costs of foreign titles.

- One possible way of dealing with the currency changes is to take advantage of prepayment plans offered by vendors on their serial lists.

- As studies by librarians in France, Germany, and the Netherlands proved, local cost studies are an effective means of calculating the cost rise on foreign titles supplied to institutions.

- There are sources of data on price trends of foreign materials that can be used for comparison purposes: France: Livres Hebdo; Germany: Buch und Buchhandel in Zahlen; and the Netherlands: Stichting Speurwerk's Boeken-Titelproduktie.

- The International Publishing Association is concerned enough about the price increases that it has polled libraries about the effects of high priced serials on the purchasing of monographs.

- In addition to being able to produce general data on the prices of monographs supplied on blanket orders, some vendors can now supply data that are institution specific. Those vendors that cannot do so are now seeking to provide such a service.

- All of the parties visited were informed about the existence of a new draft international standard for price indexes for library materials. In one case, that of the German national price study for books where standard UNESCO subject headings are already used for reporting prices and booksellers wish to use a very simplified subject scheme, the 
standard will provide justification for the continued use of the UNESCO subject system.

- A promising method to more accurately reflect price trends is to record an average price per page. This methodology is used by the German annual Buch und Buchhandel in Zahlen (Bogen Preisen or prices of "signatures") and may be useful in other studies as a measure of price changes.

- Aware of the British and German discriminatory price practices, vendors, publishing/bookselling association officials were uniformly upset about this "restraint" of trade and will be working actively to discourage these practices.

- Those organizations with computer records are best able to track price changes in library materials and provide information to customers or users. It is es- sential to provide such information to libraries for use in their budget justification and planning for collection development.

- As European vendors and libraries automate their processes, they need to be made aware of the requirements of North American libraries for library price data.

The framework for better information is there. What is needed now is the encouragement for vendors to do the work. In the long run, librarians need to operate more like business people and protect their interests. They will then notice discrepancies sooner than they did in the case of discriminatory pricing, and they will be able to be more effective in presenting their case for funds for foreign materials.

\section{REFERENCES}

1. Lawraine Wood, Average Prices of British Academic Books, 1974-1984 (Loughborough: Centre for Library and Information Management, 1984), 28p.

2. Dora Biblarz, "Reporting Book Prices: Academic Book Prices: Academic Book Price Index," Book Research Quarterly 2:83-87 (Summer 1986).

3. Kathryn A. Soupiset, "College Book Price Information," Choice 25:1047-51 (Mar. 1988).

4. Frederick C. Lynden, "The Library Materials Price Situation in the United States," LIBER Bulletin 9/10:100 (1978).

5. Morton Hein, ed., "Criteria for Price Indexes for Library Materials: Books and Serials. Final Draft Version," Draft Proposal 9230 (Copenhagen: International Organization for Standardization, Technical Committee 46, Working Group 8, Nov. 1985).

6. J. L. Schofield and A. Cooper, Average Prices of British Academic Books, 1974 (Cambridge: Univ. Cambridge, 1974), p.1.

7. Peter H. Mann, "Library Acquisitions: The Economic Constraints," The Bookseller 4199:2340 (June 14, 1986).

8. J. L. De Vries, "Afternoon Discussion, Chaired by Mr. J. R. De Groot," LIBER Bulletin 9/10:117 (1978).

9. Rebecca T. Lenzini, "Prices of U.S. and Foreign Published Materials," Bowker Annual of Library and Book Trade Information, 1987 (New York: Bowker, 1987), p.434-52.

10. Sally F. Williams, "Reporting Book Prices," Book Research Quarterly 1:86 (Winter 1985-86).

11. Stichting Speurwerk, "Titelproduktie 1985, Gemiddelde Prijzen," Boekblad 36:13 (Sept. 5, 1986).

12. "Conjoncture: Le Prix du livre a diminue de moitie en quinze ans," Livres Hebdo 7:116 (Mar. 18, 1985); INSEE, correspondence, Feb. 12, 1988.

13. Buch und Buchhandel in Zahlen 1986 (Frankfurt am Main: Buchhaendler-Vereinigung, 1986), p.51 (see previous annuals for earlier data).

14. Charles Hamaker, "Journal pricing: A Modest Proposal," Serials Librarian 11:172 (Dec. 1986/Jan. 1987).

15. Steven E. Thompson, "Reporting Book Prices: German Book Prices," Book Research Quarterly 2:82-84 (Spring 1986).

16. "Library Book and Periodical Spending" (Geneve: Union Internationale des Editeurs, June 16, 1986).

17. Rolf Griebel, "Preisindizes und Haushaltsplanung," address given at the 76th meeting of the 
German Library Association, Oldenbourg, 1986.

18. Paul Kaegbein, "National Collection Building in the Federal Republic of Germany," Journal of Academic Librarianship 13:81-85 (May 1987).

19. Mark Sandler, "Dollar Watch: Fourth Quarter Update," Library Issues 7:4 (Mar. 1987).

20. Marcia Tuttle, "The Pricing of British Journals for the North American Market," Library Resources \& Technical Services 30:72-78 (Jan./Mar. 1986).

21. Frederick C. Lynden, "Managing Rising Materials Costs," address given at the University of Oklahoma Libraries Conference on "Acquisitions, Budgets and Material Costs: Issues and Approaches," Feb. 26-27, 1987.

22. Ann Okerson, "Periodical Prices: A History and Discussion," Advances in Serials Management 1:15-16.

\section{IN FORTHCOMING ISSUES OF COLLEGE \& RESEARCH LIBRARIES}

Inventing the Electronic University by David Lewis

State Coordination of Higher Education and Academic Libraries by Vicki L. Gregory

The Political Economy of the Academic Library by Dennis P. Carrigan

College Library Friends Groups in New York, New Jersey, and Connecticut by Janet Butler Munch

Automated Collection Analysis Using the OCLC and RLG Bibliographic Databases

by Nancy P. Sanders, Edward T. O'Neill, and Stuart L. Weibel

Sources of Professional Knowledge of University Librarians by Ronald R. Powell 